\title{
In situ morphological characterization of soursop (Annona muricata L.) plants in Manabí, Ecuador
}

\section{Caracterización morfológica in situ de plantas de guanábana (Annona muricata L.) en Manabí, Ecuador}

\author{
Moreira-Macías Ricardo, ${ }^{1}$ Rodríguez Héctor, ${ }^{2}$ Héctor-Ardisana Eduardo, ${ }^{3}$ Feicán-Mejia Carlos, ${ }^{1}$ \\ Mestanza Velasco Saúl Anibal, ${ }^{1}$ Viera Arroyo William ${ }^{1}$
}

\begin{abstract}
Soursop (Annona muricata L.) germplasm, from the central region of the Ecuadorian littoral, has diverse phenotypic characteristics, which have been little studied. The main objective of this research was to characterize in situ the morphological variability of 60 accessions of soursop. The morphological traits were evaluated using 20 quantitative and 10 qualitative variables of the plant and the fruit. Multivariate statistical methods were used as principal components, hierarchical conglomerate aggregation, discriminant and correlation analysis (Pearson) were performed. Descriptive analysis such as central tendency and dispersion (coefficient of variation, range, mean and standard deviation) were determined for the quantitative data; while frequencies were calculated for qualitative data. In terms of morphological traits, $74 \%$ of the total variability was explained by the fourth component. Three conglomerates of similarity were formed, in which the height, diameter of canopy and fruit number per tree, were the characters of greater contribution for its conformation
\end{abstract}

\section{Keywords}

Descriptor, variability, phenotypic, Annonaceae.

\begin{abstract}
Resumen
El germoplasma de guanábana (Annona muricata L.) de la región central del litoral ecuatoriano tiene diversas características fenotípicas, que han sido poco estudiadas. El objetivo principal de esta investigación fue caracterizar in situ la variabilidad morfológica de 60 plantas de guanábana. Los rasgos morfológicos se evaluaron utilizando 20 variables cuantitativas y 10 cualitativas de la planta y el fruto. Para ello, se utilizaron métodos estadísticos multivariados como componentes principales, se realizó agregación jerárquica de conglomerados, análisis discriminante y de correlación (Pearson). Se determinaron análisis descriptivos tales como tendencia central y dispersión (coeficiente de variación, rango, media y desviación estándar) para los datos cuantitativos; mientras que las frecuencias se calcularon para datos cualitativos. En términos de rasgos morfológicos, el cuarto componente explica el 74 \% de la variabilidad total. Se formaron tres conglomerados de similitud, en los que la altura, el diámetro del dosel y el número de frutos por árbol, fueron los caracteres de mayor contribución para su conformación.
\end{abstract}

\section{Palabras clave}

Descriptor, variabilidad, fenotípico, Annonaceae.

\section{Introduction}

Soursop (Annona muricata L.), also called "guanábana" in some countries of South America, is a species of the Annonaceae family. Its center of geographic diversity is in the north of South America and it is distributed in different tropical regions of the world (Love and Paull, 2011). This fruit is highly appreciated due its excellent flavor and nutraceutical properties. In addition, some therapeutic effects

1 Instituto Nacional de Investigaciones Agropecuarias. Programa de Fruticultura (INIAP), Ecuador (Ricardo.moreira@iniap. gob.ec, Carlos.feican@iniap.gob.ec, Saul.mestanzav@iniap.gob.ec, william.viera@iniap.gob.ec)

2 Universidad Agraria de La Habana, Cuba. Facultad de Agronomía, San José de las Lajas, Mayabeque (Rodriguez.morell66@ gmail.com)

3 Universidad Técnica de Manabí, Ecuador. Facultad de Agronomía. Lodana, Santa Ana (ehectorardisana@gmail.com) 
are related to fight against cancer cells (Zorofchian et al., 2015; Jemimah et al., 2016). For that reasons, the markets of the USA, Europe and Asia demand this appetizing fruit (Pro Ecuador, 2014).

In Ecuador, soursop cultivation is a growing business and offers great opportunities due to there is big demand and fruit obtain high prices (Moreira and Héctor, 2014). Currently an area of 800 ha is estimated for this crop, although official data are not available. (Personal information obtained from the Fruticulture Program of INIAP, Litoral Sur Experimental Station.

Morphological characterization of the genetic resources of several species of Annonaceae has been of transcendental importance to register particular traits and to differentiate their taxonomic, phenotypic and genetic through qualitative and quantitative attributes that are highly heritable and observable, as well as expressible in most of the environments (Suratman, and Mulyani, 2015). The systematic characterization has allowed to reveal the variation within the collections and select the most elite genotypes for their cultivation.

Fruit physico-chemical characteristics (size, shape, types of emergencies, concentration of total soluble solids, acidity and others) have been investigated in the central littoral of Ecuador (Moreira et al., 2016), however the phenotypic features of the plant are not have been studied, Therefore, the principal goal of this study was to determine the morpho-agronomic characteristics of a soursop population, established wildly in the province of Manabí, Ecuador.

\section{Materials and Methods}

\section{Germplasm location}

The research was carried out in an area of $1273.45 \mathrm{~km}^{2}$ distributed between the cantons Jipijapa, Paján, 24 de Mayo and Olmedo in the south of Manabí, Ecuador. This zone has a dry tropical climate with an average temperature of $25.85^{\circ} \mathrm{C}, 81.45 \%$ of relative humidity and $1484 \mathrm{~mm}$ of annual accumulated precipitation (INAMHI, 2014). For this study, 60 soursop trees (accessions) in productive stage were chosen (Table 1).

Prior to the morphoagronomic characterization of the accessions, the location and distribution of the accessions in the study area was determined, through the Global Positioning System (GPS), with a Garmin ${ }^{\circledR}$ GPS 12 model. Latitude, longitude and altitude above sea level were determined. Subsequently, with the database obtained, the geographical distribution of the accessions on a satellite map was graphed with the use of MAPCREATOR v.19 software, in order to register and visualize its geospatial distribution (Table.1).

Table 1. Population of soursop selected from southern of Manabí, Ecuador

\begin{tabular}{|l|l|l|l|l|l|}
\hline \multirow{2}{*}{ Individuals } & \multicolumn{2}{|c|}{ Location } & \multicolumn{2}{c|}{ Cordinates } & \multicolumn{1}{c|}{ Elevation } \\
\cline { 2 - 6 } & \multicolumn{1}{|c|}{ Site } & Cantons & \multicolumn{1}{c|}{ Latitude } & \multicolumn{1}{c|}{ Longitude } & (m.a.s.I) \\
\hline G-1 & El Salitre & Jipijapa & $01^{\circ} 29.942^{\prime}$ & $80^{\circ} 31.437^{\prime}$ & 437 \\
\hline G-2 & El Salitre & Jipijapa & $01^{\circ} 29.943^{\prime}$ & $80^{\circ} 31.458^{\prime}$ & 424 \\
\hline G-3 & El Corozo & Jipijapa & $01^{\circ} 30.020^{\prime}$ & $80^{\circ} 31.412^{\prime}$ & 402 \\
\hline G-4 & Los Vergeles & Jipijapa & $01^{\circ} 29.838^{\prime}$ & $80^{\circ} 32.450^{\prime}$ & 419 \\
\hline G-5 & Los Vergeles & Jipijapa & $01^{\circ} 29.830^{\prime}$ & $80^{\circ} 32.451^{\prime}$ & 407 \\
\hline G-6 & EL Corozo & Jipijapa & $01^{\circ} 30.021^{\prime \prime}$ & $80^{\circ} 33.510$ & 365 \\
\hline G-7 & El Corozo & Jipijapa & $01^{\circ} 29.660^{\prime}$ & $80^{\circ} 31.590^{\prime}$ & 565 \\
\hline G-8 & El Corozo & Jipijapa & $01^{\circ} 29.644^{\prime \prime}$ & $80^{\circ} 31.571$ & 509 \\
\hline G-9 & Los Vergeles & Jipijapa & $01^{\circ} 30.004^{\prime}$ & $80^{\circ} 32.010^{\prime}$ & 441 \\
\hline
\end{tabular}




\begin{tabular}{|c|c|c|c|c|c|}
\hline G-10 & El Anegado & Jipijapa & $01^{\circ} 27.382^{\prime}$ & $80^{\circ} 33.195^{\prime}$ & 355 \\
\hline G-11 & Pedro Pablo Gómez & Jipijapa & $01^{\circ} 34.527^{\prime}$ & $80^{\circ} 30.881^{\prime}$ & 246 \\
\hline G-12 & Francisco de Orellana & Jipijapa & $01^{\circ} 30.596^{\prime}$ & $80^{\circ} 30.451^{\prime}$ & 565 \\
\hline G-13 & Cerro Lucía & Jipijapa & $01^{\circ} 29.074^{\prime}$ & $80^{\circ} 31.086^{\prime}$ & 668 \\
\hline G-14 & El Corozo & Jipijapa & $01^{\circ} 29.720^{\prime}$ & $80^{\circ} 31.916^{\prime}$ & 420 \\
\hline G-15 & El Páramo & Jipijapa & $01^{\circ} 30.557^{\prime \prime}$ & $80^{\circ} 31.789$ & 536 \\
\hline G-16 & Zapotal & Paján & $01^{\circ} .33 .804^{\prime}$ & $80^{\circ} 27.121^{\prime}$ & 163 \\
\hline G-17 & Zapotal & Paján & $01^{\circ} 33.487^{\prime}$ & $80^{\circ} 27.349^{\prime}$ & 161 \\
\hline G-18 & Zapotal & Paján & $01^{\circ} 33,084^{\prime \prime}$ & $80^{\circ} 27.786$ & 174 \\
\hline G-19 & El Resbalón & Paján & $01^{\circ} 32.483^{\prime \prime}$ & $80^{\circ} 28.271$ & 190 \\
\hline G-20 & San Miguel & Paján & $01^{\circ} 32.006^{\prime \prime}$ & $80^{\circ} 29.158$ & 227 \\
\hline G-21 & San Miguel & Paján & $01^{\circ} 32.095^{\prime \prime}$ & $80^{\circ} 29.878$ & 232 \\
\hline G-22 & Camposano & Paján & $01^{\circ} 35.999^{\prime \prime}$ & $80^{\circ} 23.106$ & 196 \\
\hline G-23 & Camposano & Paján & $01^{\circ} 35.803^{\prime}$ & $80^{\circ} 22.492^{\prime}$ & 197 \\
\hline G-24 & La Crucita & Paján & $01^{\circ} 35.766^{\prime}$ & $80^{\circ} 22.344$ & 214 \\
\hline G-25 & La Crucita & Paján & $01^{\circ} 34.848^{\prime \prime}$ & $80^{\circ} 22.050$ & 234 \\
\hline G-26 & Tierra Amarilla & Paján & $01^{\circ} 29.086^{\prime}$ & $80^{\circ} 21.936^{\prime}$ & 136 \\
\hline G-27 & El Aji & Paján & $01^{\circ} 31.158^{\prime}$ & $80^{\circ} 22.177^{\prime}$ & 118 \\
\hline G-28 & La Esperanza & Paján & $01^{\circ} 35.388^{\prime}$ & $80^{\circ} 21.892^{\prime}$ & 112 \\
\hline G-29 & La Poza & Paján & $01^{\circ} 35.119^{\prime}$ & $80^{\circ} 21.951^{\prime}$ & 200 \\
\hline G-30 & La Poza & Paján & $01^{\circ} 35.022^{\prime}$ & $80^{\circ} 21.985$ & 206 \\
\hline G-31 & Bellavista & 24 de Mayo & $01^{\circ} 21.518^{\prime}$ & $80^{\circ} 17.706^{\prime}$ & 218 \\
\hline G-32 & El Bejuco & 24 de Mayo & $01^{\circ} 20.779^{\prime}$ & $80^{\circ} 18.720^{\prime}$ & 152 \\
\hline G-33 & El Bejuco & 24 de Mayo & $0,1^{\circ} 20.390^{\prime}$ & $80^{\circ} 18.488^{\prime}$ & 135 \\
\hline G-34 & La Subida & 24 de Mayo & $01^{\circ} 19.586^{\prime}$ & $80^{\circ} 20.187^{\prime}$ & 136 \\
\hline G-35 & El Bejuco Grande & 24 de Mayo & $01^{\circ} 20.202^{\prime}$ & $80^{\circ} 22.205^{\prime}$ & 427 \\
\hline G-36 & El Bejuco Grande & 24 de Mayo & $01^{\circ} 20.317^{\prime}$ & $80^{\circ} 22.235^{\prime}$ & 429 \\
\hline G-37 & El Cruce-Los Palmares & 24 de Mayo & $01^{\circ} .18 .829^{\prime}$ & $80^{\circ} 22.173^{\prime}$ & 424 \\
\hline G-38 & La Guinea & 24 de Mayo & $01^{\circ} 20.369^{\prime}$ & $80^{\circ} 22.821^{\prime}$ & 445 \\
\hline G-39 & Las Lozas & 24 de Mayo & $01^{\circ} 20078^{\prime}$ & $80^{\circ} 24.424^{\prime}$ & 472 \\
\hline G-40 & Las Lozas & 24 de Mayo & $01^{\circ} 20.081$ & $80^{\circ} 24.421$ & 477 \\
\hline G-41 & El Bejuco & 24 de Mayo & $01^{\circ} 20.232^{\prime}$ & $80^{\circ} 26.164$ & 500 \\
\hline G-42 & El Carmen & 24 de Mayo & $01^{\circ} 20.449^{\prime \prime}$ & $80^{\circ} 22.886$ & 466 \\
\hline G-43 & La Naranjita & 24 de Mayo & $01^{\circ} 25.417^{\prime}$ & $80^{\circ} 26.509^{\prime}$ & 452 \\
\hline G-44 & La Naranjita & 24 de Mayo & $01^{\circ} 25.134^{\prime \prime}$ & $80^{\circ} 25.203$ & 426 \\
\hline G-45 & Cuatro Caminos & 24 de Mayo & $01^{\circ} 24.847^{\prime}$ & $80^{\circ} 24.734^{\prime}$ & 417 \\
\hline G-46 & La Norma & Olmedo & $01^{\circ} 26.358^{\prime}$ & $80^{\circ} .11 .794^{\prime}$ & 76 \\
\hline G-47 & La Norma & Olmedo & $01^{\circ} 26.268^{\prime}$ & $80^{\circ} 14.209$ & 72 \\
\hline G-48 & La Pampa & Olmedo & $01^{\circ} 25.934^{\prime}$ & $80^{\circ} 14.152^{\prime}$ & 77 \\
\hline G-49 & La Pampa & Olmedo & $01^{\circ} 25.291^{\prime}$ & $80^{\circ} 14.032^{\prime}$ & 62 \\
\hline G-50 & La Cruz & Olmedo & $01^{\circ} 23.040^{\prime}$ & $80^{\circ} 13.705^{\prime}$ & 91 \\
\hline G-51 & Las Navas & Olmedo & $01^{\circ} 24.994^{\prime}$ & $80^{\circ} 13.098^{\prime}$ & 86 \\
\hline G-52 & Las Navas & Olmedo & $01^{\circ} 24.965^{\prime \prime}$ & $80^{\circ} 13.201$ & 114 \\
\hline G-53 & La Italia Afuera & Olmedo & $01^{\circ} 24.404^{\prime}$ & $80^{\circ} 13.762$ & 74 \\
\hline G-54 & La Italia Adentro & Olmedo & $01^{\circ} 24.349^{\prime}$ & $80^{\circ} 13.863^{\prime}$ & 63 \\
\hline G-55 & La Italia Adentro & Olmedo & $01^{\circ} 24.153^{\prime}$ & $80^{\circ} 13.927$ & 77 \\
\hline G-56 & El Zapote & Olmedo & $01^{\circ} 28.075^{\prime}$ & $80^{\circ} 15.253^{\prime}$ & 111 \\
\hline G-57 & El Zapote & Olmedo & $01^{\circ} 28.103^{\prime}$ & $80^{\circ} 15.259^{\prime}$ & 190 \\
\hline G-58 & El Zapote & Olmedo & $01^{\circ} 28.308^{\prime}$ & $80^{\circ} 14.728^{\prime}$ & 111 \\
\hline G-59 & La Canoa & Olmedo & $01^{\circ} 25.350^{\prime}$ & $80^{\circ} 13.977^{\prime}$ & 105 \\
\hline G-60 & La Canoa & Olmedo & $01^{\circ} 25,729^{\prime}$ & $80^{\circ} 14,174^{\prime}$ & 52 \\
\hline
\end{tabular}


Figure 1. Global geographical posilioning (GPS) of 60 accessions of the soursop germplasm in southern of Manabí, Ecuador

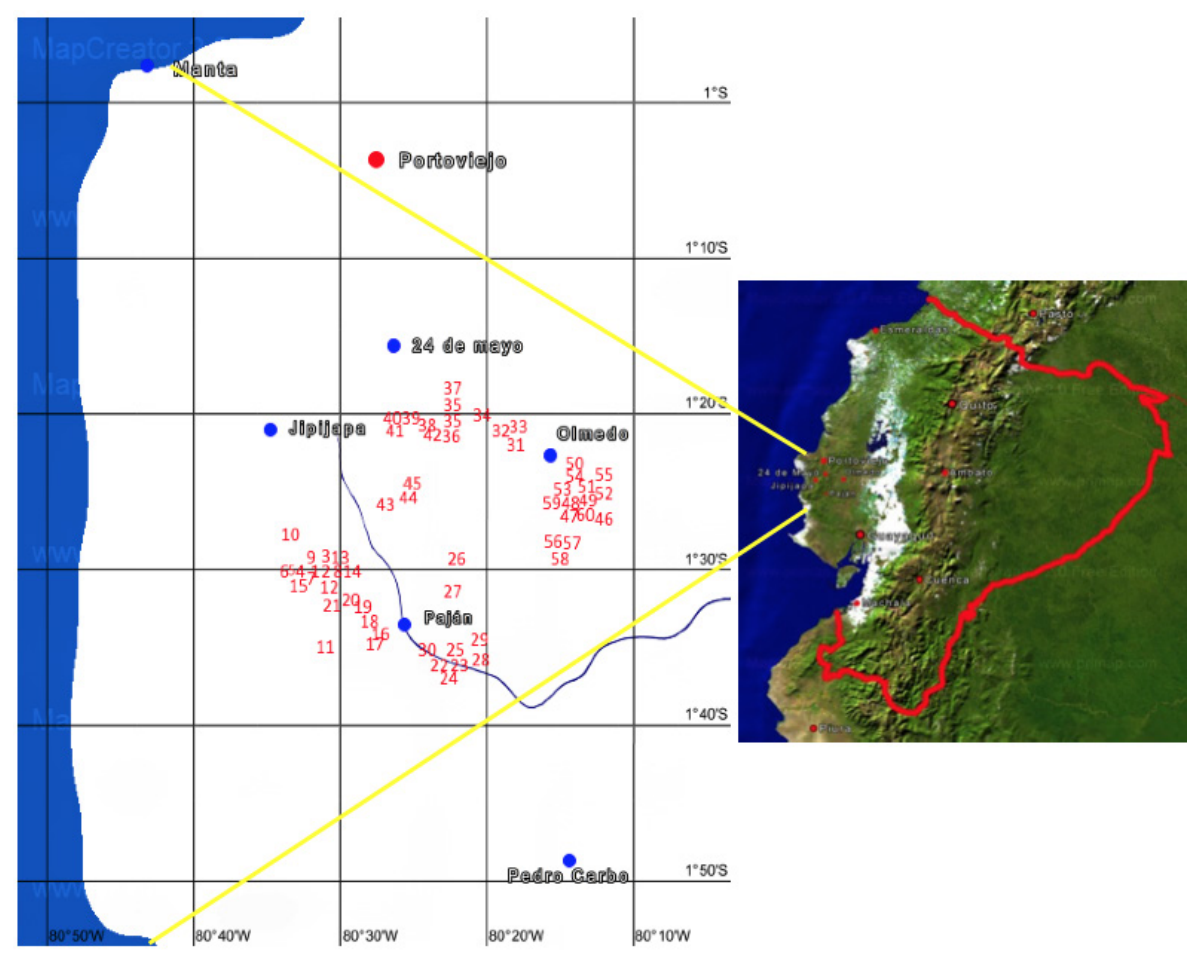

\section{Characterization}

The morphological characterization was carried out using 17 plant descriptors (Bioversity International y CHERLA, 2008), being 9 quantitative (number of fruits per tree, diameter of the canopy $(\mathrm{m})$, tree height $(\mathrm{m})$, number of nodes per meter of branch, leaf length $(\mathrm{cm})$, leaf width $(\mathrm{cm})$, petiole length $(\mathrm{cm})$, petiole thickness $(\mathrm{mm})$, and number of primary leaf veins) and 10 qualitative (trunk color, young branch color, trunk ramification, leaf shape, leaf base shape, leaf apex shape, color of the mature leaves, leaf margin, fruit shape and form of emergencies of the exocarp). Ten observations per tree (accession) were made for each trait, with the exception of the number of nodes per meter of branch in which five observations were measured per tree. These evaluations were carried out during the dry period of the year, which coincides with the fruiting stage of the tree.

\section{Analyses}

In terms of quantitative descriptors, a descriptive analysis was made (mean, standard deviation, minimum value, maximum value and variation coefficient), as well as Pearson correlations. In terms of qualitative descriptors, a frequency analysis was carried out and the results were expressed in percentages. Principal component analysis (PCA) was made based on the Pearson correlation matrix selecting descriptors that showing greatest contribution in the morphologi- 
cal characterization. The selection criteria of eigenvectors involved the values closest to the highest value and the percentage contribution of each axis to the total variability.

A cluster analysis was performed to achieve the grouping of individuals according to their similarities, including quantitative and qualitative characteristics through the Gower distance matrix and the Ward method as a form of ascending hierarchical aggregation. A discriminant analysis was performed to verify the correspondence of the accessions within the dendrogram conglomerates, the statistical data analyses was made using the INFOStat software (Di Rienzo et al., 2016, free version).

Each tree of the wild studied population was considered as an accession, in which the age of the trees was variable,; however it ensured that all of them were of productive age.

\section{Results and Discussion}

Five descriptors (Number of fruits, crown diameter, tree height, leaf petiole length and thickness of leaf petiole) showed coefficient of variation values above $20 \%$, which is considered by Franco and Hidalgo (2003) as the minimum limit for the expression of variability (Table 2). These authors consider that descriptors with values lower than $20 \%$ should be considered as low variability; in this study the descriptors that did not reach this level were nodes per meter of branch, length of leaf, leaf width and number of primary veins per leaf. Number of fruits was the descriptor that showed the greatest variability (CV: 60, 11). In conditions of commercial cultivation, the amount of fruits per tree is mainly due to the management of the plantation plus the genetic constitution of the trees. However, the locations where the germplasm was studied have the same climate, and the trees don't receive any cultivation work. Therefore, it woud be that the number of fruits per tree would be due to the genetic structure of each accession. This character is particularly important because is related to productivity and profitability, being priority in genetic improvement programs (Jameel et al, 2015).

Table 2. Quantitative morphological descriptors of the 60 soursop accessions characterized in situ in southern of Manabí

\begin{tabular}{|l|l|l|l|l|l|}
\hline \multicolumn{1}{|c|}{ DESCRIPTORS } & \multicolumn{1}{c|}{ Min } & \multicolumn{1}{c|}{ Max } & \multicolumn{1}{c|}{ Mean } & \multicolumn{1}{c|}{ Std } & \multicolumn{1}{c|}{ CV (\%) } \\
\hline Number of fruits & 20.00 & 250.00 & 87.61 & 52.67 & 60.11 \\
\hline Crown diameter $(\mathrm{m})$ & 2.61 & 18.00 & 8.75 & 3.43 & 39.15 \\
\hline Tree height $(\mathrm{m})$ & 3.00 & 22.00 & 10.27 & 3.60 & 35.03 \\
\hline Nodes per meter of branch & 36.60 & 65.20 & 51.13 & 7.86 & 15.36 \\
\hline Length of leaf (cm) & 7.89 & 18.04 & 12.82 & 1.67 & 13.05 \\
\hline leaf width (cm) & 3.88 & 7.16 & 5.40 & 0.71 & 13.15 \\
\hline Leaf petiole length (cm) & 0.46 & 2.08 & 0.84 & 0.26 & 30.91 \\
\hline Thickness of leaf petiole $(\mathrm{mm})$ & 1.00 & 2.30 & 1.64 & 0.38 & 23.46 \\
\hline $\mathrm{N}^{\circ}$ of primary veins per leaf & 15.00 & 24.00 & 18.74 & 2.06 & 11.00 \\
\hline
\end{tabular}

Based on the considerations about the variability expressed by Franco and Hidalgo (2003) and Hernández (2013), it can be suggested, that there is greater variability of the Ecuadorian soursop germplasm compared to the germplasm studied by Padmini et al. (2013), in which 448 soursop accessions were characterized, discarded the length of the leaf, the length of the petiole of the leaf (due to low variation coefficient), the shape of the apex and the base of the leaf 
(in both case only one form), the margin of the leaf (entire $100 \%$ ), and the color of the mature leaf (dark green $100 \%$ ), characters that were highly variable in the Ecuadorian germplasm.

No significant correlation coefficients were observed between the morphological descriptors, except between the number of fruits and the canopy diameter, which showed a highly significant positive correlation, although with a medium coefficient $(r=0.54)$. Denoting the implication and importance of the number of fruit in the productivity. It is necessary to carry out more research because this result suggests that trees with a greater diameter of the canopy are more productive in terms of number of fruits than those of vertical growth. As this study was development in wild trees that do not receive any cultivation work, this information would be very valuable in breeding programs.

The analysis of main components allowed us to illustrate the relationship between the quantitative variables studied and their participation in the explanation of germplasm variability. The contribution percentage of the first four components was $74 \%$ of the total variability. The first component (PC1) contributed with $32 \%$ of the variability, followed by the second component (PC2) with $22 \%$, the third component contributed with $12 \%$ and the fourth $9 \%$, respectively (Table 3). In the PC1, the descriptors that contributed most to the variability were: leaf width, number of primary veins per leaf, leaf length and petiole length variables. The mentioned variables are related to the uptake of sun energy that is a determining factor in the photosynthetic activity and photoassimilates flow (Meza y Bautista, 1999). In the PC2, the descriptors that contributed most to the variability were: Number of fruits, Canopy diameter and tree height, variables that determine the productivity and structure of the tree.

In Colombia, Miranda et al. (2000) observed the formation of five groups and reported only oblong-lanceolate leaves with acute apices, a characteristic that denotes a lower variability of this germplasm in situ with respect to that observed in southern Manabi, in which four types appeared of leaves in terms of their shape and three different types of apices. These authors also observed leaves with average lengths of $12.00 \mathrm{~cm}$ and $4.78 \mathrm{~cm}$ wide, while in Manabí average values greater than $12.88 \mathrm{~cm}$ and $5.45 \mathrm{~cm}$, respectively were observed. The aforementioned authors did not use the descriptors used in the present investigation, where the length and width of the leaf petiole, the number of ribs on the leaf and the type of undulation of the leaf were discriminant.

In base to the expressed by Franco and Hidalgo (2003) and Hernández (2013), about the variability we can suggest the existence of greater variability of the Ecuadorian soursop germplasm versus other germplasms such as the studied by Padmini et al. (2013), who in the characterization of a germplasm of 448 soursop accessions in Sri Lanka, Asia, with the use of 45 characters, discarded the length of the leaf, the length of the petiole of the leaf, the shape of the apex and of the base of the leaf, the undulation of the leaf, and the color of the mature leaf, characters that instead were highly variable in the Ecuadorian germplasm.

The hierarchical cluster analysis of Ward allowed the conformation of three similarity groups (Fig. 2), which expressed a cofenetic correlation of 0.57 , which represents that there is adequate reliability in the analyzes. 
Table 3. Variability explained in the PCA for the quantitative morphological descriptors

\begin{tabular}{|c|c|c|c|c|c|}
\hline \multirow{2}{*}{\multicolumn{2}{|c|}{ Variables }} & \multicolumn{4}{|c|}{ Contribution porcentaje } \\
\hline & & PC1 & PC2 & PC3 & PC4 \\
\hline \multicolumn{2}{|l|}{ Number of fruits } & 0.47 & 0.60 & -0.40 & 0.03 \\
\hline \multicolumn{2}{|c|}{ Canopy diameter (m) } & 0.48 & 0.74 & 0.04 & -0.11 \\
\hline \multicolumn{2}{|c|}{ Tree height $(\mathrm{m})$} & 0.54 & 0.63 & 0.04 & 0.01 \\
\hline \multicolumn{2}{|c|}{ Nodes per meter of branch } & -0.08 & 0.34 & 0.88 & -0.16 \\
\hline \multicolumn{2}{|c|}{ Leaf length $(\mathrm{cm})$} & 0.63 & -0.38 & -0.17 & -0.39 \\
\hline \multicolumn{2}{|l|}{ Leaf width $(\mathrm{cm})$} & 0.81 & -0.18 & 0.01 & -0.22 \\
\hline \multicolumn{2}{|l|}{ Petiole length (cm) } & 0.62 & -0.26 & 0.18 & 0.59 \\
\hline \multicolumn{2}{|c|}{ Thickness of petiole $(\mathrm{mm})$} & 0.53 & -0.50 & 0.20 & -0.28 \\
\hline \multicolumn{2}{|c|}{$\mathrm{N}^{\circ}$ of primary veins per leaf } & 0.66 & -0.19 & 0.15 & 0.34 \\
\hline \multirow{2}{*}{ Initial eigenvalues } & Explained variance (\%) & 32.00 & 22.00 & 12.00 & 9.00 \\
\hline & $\%$ accumulated & 32.00 & 54.00 & 66.00 & 74.00 \\
\hline
\end{tabular}

Figure 2. Dendrogram obtained by Ward's hierarchical grouping of the quantitative and qualitative morphological descriptors of 60 in situ germplasm accessions of soursop from the central regions of ecuadorian littoral. Cofenetics correlation $r=0.57$

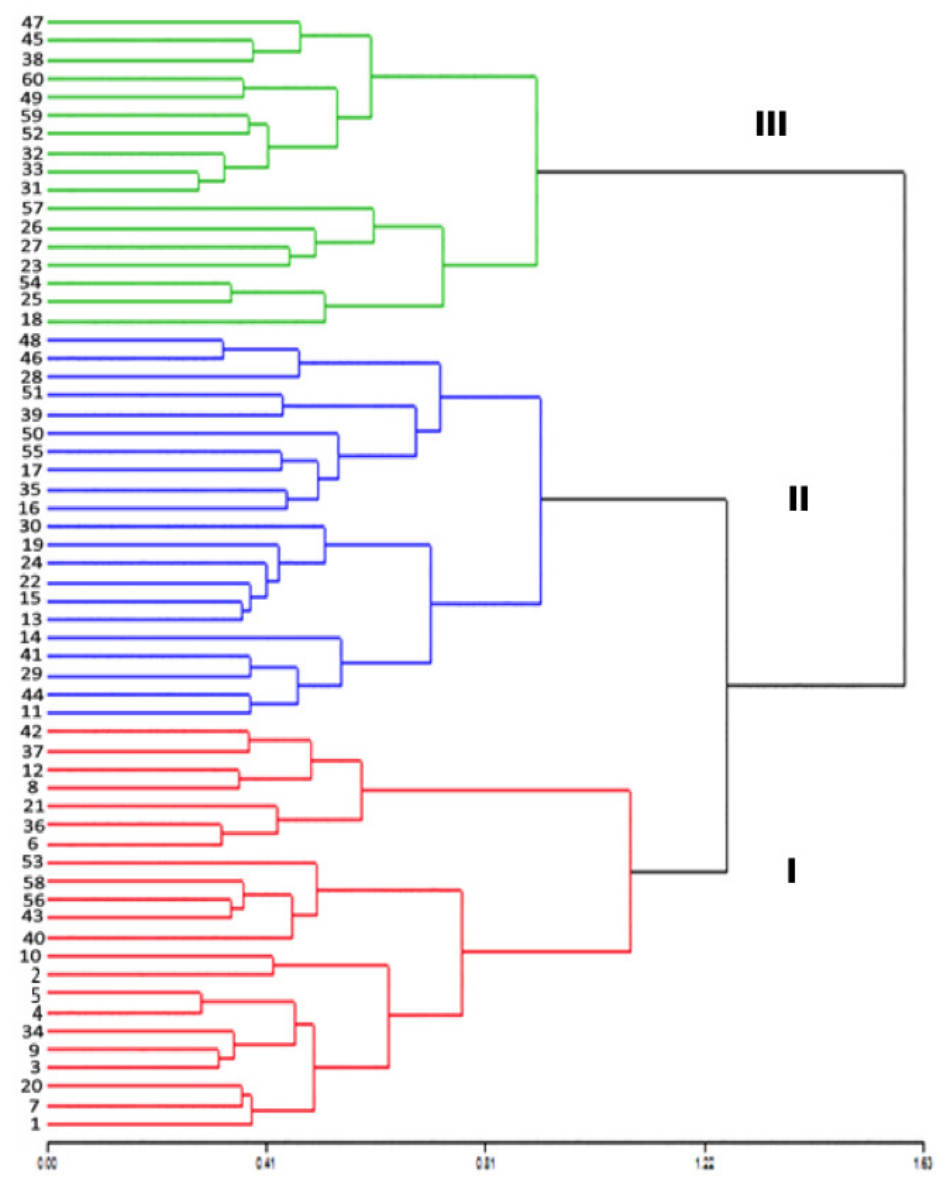


The discriminant analysis showed that only $6.7 \%$, corresponding to four accessions, had an incorrect classification, that is to say, they presented more similarities with plants from other conglomerates than with those of their own. On the other hand, $93.34 \%$ of the accessions (56 of 60) presented an adequate classification, which indicates that they corresponded to the right conglomerate (Table 4). The group 1 consisted of 22 accessions, group 2 of 21 accessions and group 3 of 17 accessions.

Table 4. Cross classification (apparent error) of the clusters by discriminant analysis of the morphoagronomic descriptors from the in situ germplasm accessions of soursop from the central regions of the ecuadorian Litoral

\begin{tabular}{|l|c|c|c|c|c|}
\hline & \multicolumn{6}{|c|}{ Predicted Membership group } & Total expected & Error \\
\hline Conglomerate & 1 & 2 & 3 & & \\
\hline 1 & 21 & 0 & 1 & 22 & 4.55 \\
\hline 2 & 2 & 18 & 1 & 21 & 14.29 \\
\hline 3 & 0 & 0 & 17 & 17 & 0.00 \\
\hline Real total & 23 & 18 & 19 & 60 & 6.67 \\
\hline \multicolumn{7}{l}{ Correct classification percentage $=93.33$} \\
\hline
\end{tabular}

Conglomerate 1 contains the accessions showing the lowest average number of fruits (57.23), the smallest diameter of the crown $(7.03 \mathrm{~m})$ and lowest height $(8.51 \mathrm{~m})$. They presented average values of magnitude of the leaf in comparison to the other conglomerates, as well as the lowest number of nodes per meter of branch (50.14). conglomerate 2 included accessions showing the largest number of fruit (121.71) and with the largest canopy diameter (11.70 m) and largest height $(12.67 \mathrm{~m})$. It also grouped the accessions with the highest values in terms of the descriptors that determine the magnitude and carrying capacity of sap of the leaf such as leaf length and number of primary veins per leaf. The conglomerate 3 integrated the accessions showing an intermediate amount of number of fruits (84.82), number of nodes per branch (53.20), number of ribs per leaf (17.54), lowest values of leaf length $(11.66 \mathrm{~cm})$ and leaf width $(4.88 \mathrm{~cm})$.

The present study described six types of trunk coloration and the young branch, four types of shape leaf, two types of the leaf base, three types of the leaf apex, three colorations of the mature leaf and three types of the margin of the leaf blade (Table 5).

Regarding the expression of the qualitative descriptors in the conglomerates conformation, differences were observed in the color of the trunk. Conglomerates 1 and 3 presented mainly greenish-brown color (31.81\% and $35.29 \%$, respectively), while conglomerate 2 showed dark brown color $(28.57 \%)$. The color of the young branch showed a predominance of light brown in the conglomerates 1, 2 (63.64 \%, $38.09 \%$, respectively). Conglomerate 3 had trees with greenish-brown branches color (35.29\%). Trees conformed by a single main stem were in all conglomerates $(68.18 \%, 61.90 \%$ and $36.29 \%$ in the conglomerates 1,2 and 3, respectively). Lanceolate shape of leaf was predominant in conglomerates 1 and 3 (95.45 \% and 70.59 $\%$, respectively); while conglomerate 2 had less percentage (47.62 \%). The acute form of the leaf base was observed in high percentage in all conglomerates $(90.91 \%$ conglomerate 1,100 $\%$ conglomerate 2 and $70.59 \%$ conglomerate 3 ). 
Table 5. Qualitative morphological descriptors of 60 accessions in situ of soursop germplasm from southern of Manabí, Ecuafor

\begin{tabular}{|c|c|c|c|c|c|c|}
\hline CHARACTER & & & OBSERVED & ARIABILIT & & \\
\hline Trunk colour & $\begin{array}{l}\text { Light Brown } \\
20\end{array}$ & $\begin{array}{l}\text { Brown } \\
11.67\end{array}$ & $\begin{array}{l}\text { Dark } \\
\text { brown } \\
18,33\end{array}$ & $\begin{array}{l}\text { Brown } \\
\text { greenish } \\
30\end{array}$ & $\begin{array}{l}\text { Brown } \\
\text { reddish } \\
15\end{array}$ & $\begin{array}{l}\text { Brown } \\
\text { whitish } \\
5\end{array}$ \\
\hline Young branch color & 41.67 & 25.00 & 16.67 & 10.00 & 1.66 & 5.00 \\
\hline \multirow[t]{2}{*}{ Trunk ramification } & 50 & & 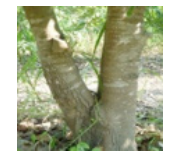 & & 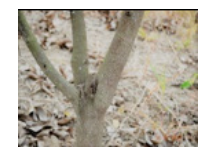 & \\
\hline & $\begin{array}{l}\text { One branch } \\
56.67\end{array}$ & & $\begin{array}{l}\text { Two } \\
\text { branches } \\
26.67\end{array}$ & & $\begin{array}{l}\text { Three o more } \\
\text { branches } \\
16.67\end{array}$ & \\
\hline \multirow[t]{2}{*}{ Leaf shape } & & & & & & \\
\hline & & $\begin{array}{l}\text { Ovate } \\
3.33\end{array}$ & $\begin{array}{l}\text { Elliptic } \\
13.33\end{array}$ & $\begin{array}{l}\text { Abovate } \\
18,33\end{array}$ & $\begin{array}{l}\text { Lanceolate } \\
65.00\end{array}$ & \\
\hline \multirow[t]{2}{*}{ Shape of leaf base } & & & & & & \\
\hline & & $\begin{array}{l}\text { Acute } \\
88.33\end{array}$ & & $\begin{array}{l}\text { Obtuse } \\
11.67\end{array}$ & & \\
\hline \multirow[t]{2}{*}{ Shape of leaf apex } & & & & & & \\
\hline & $\begin{array}{l}\text { Acute } \\
76.67\end{array}$ & & $\begin{array}{l}\text { Rounded } \\
10.00\end{array}$ & & $\begin{array}{l}\text { Acuminate } \\
13.33\end{array}$ & \\
\hline \multirow[t]{2}{*}{ Mature leaf color } & & & & & & \\
\hline & $\begin{array}{l}\text { Light green } \\
15\end{array}$ & & $\begin{array}{l}\text { Green } \\
56.67\end{array}$ & & $\begin{array}{l}\text { Dark green } \\
28.33\end{array}$ & \\
\hline \multirow[t]{2}{*}{ Leaf margin } & & & & & & \\
\hline & $\begin{array}{l}\text { Entire } \\
61.67\end{array}$ & & $\begin{array}{l}\text { Ondulate } \\
10.00\end{array}$ & & $\begin{array}{l}\text { Semi ondulate } \\
28.33\end{array}$ & \\
\hline
\end{tabular}


Despite the major features presented, different frequencies of the qualitative descriptors in the three conglomerates studied constitute an evidence of the existence of phenotypic variability in the soursop germplasm that was in situ.characterized.

Miranda et al. (2000) in study development in Colombia, observed the formation of five groups using the conglomerate analyses. These authors reported only the presence of oblonglanceolate shape of leaves with acute apex, denoting a lower variability respect to the variability observed in southern of Manabi which showed four types of leave shape and three types of apex. The results of this research partially coincide with the results obtained by Constance et al. (2015), who found that the length and width of the leaf and number of fruits were determinants to reveal the variability in 42 soursop accessions.

The lanceolate leaf shape was predominant in this study, coinciding with Castañeda (2014), who found the same predominate shape in the Annonaceae species. The presence of ondulate and semi ondulate leaves in these study, was also observed, as well as, four types of leaf shape, two types of leaf base shape, three types of leaf apex shape, and three mature leaf colors.

The most frequent forms of the fruit in the evaluated germplasm were the elongated ovoid and the ovoid, followed by the troncovoid type (Table 6). The rest were distributed among cordiform, spherical and reniform fruits.

Table 6. Predominant forms of the fruits of in situ soursop germplasm from southern of Manabí, Ecuador

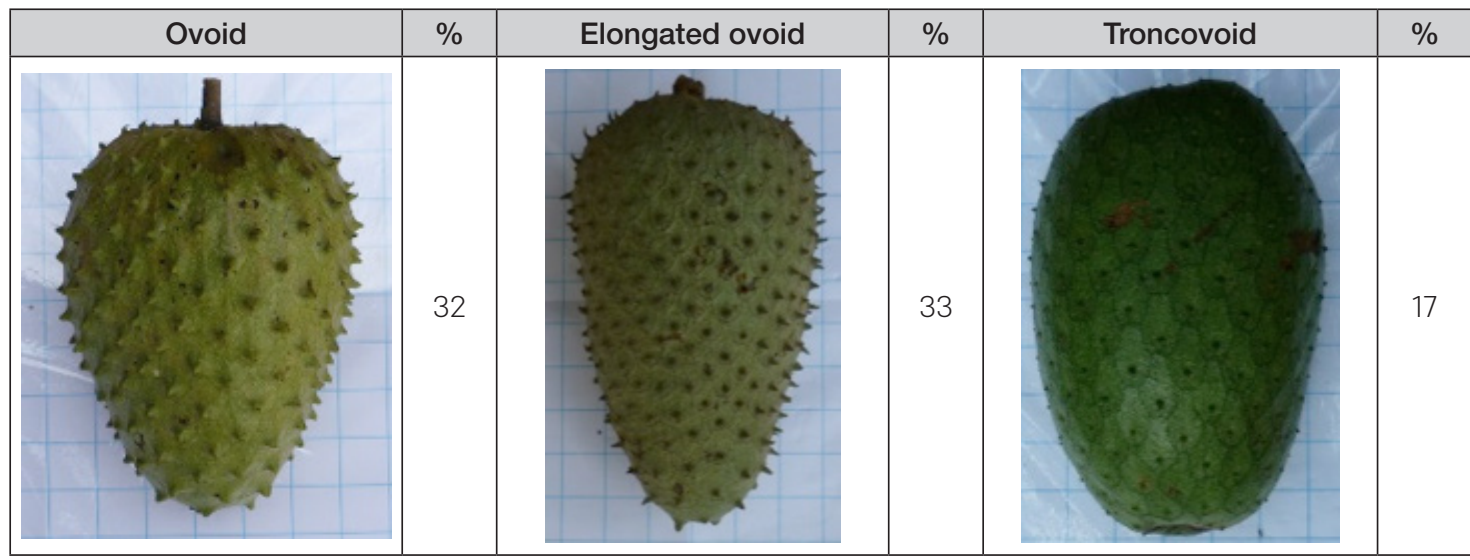

The studied germplasm presented several forms of spines of the exocarp, of which the most common one was the acute apex of up to $5 \mathrm{~mm}$ in length and not very dense in the fruit (58\%) (Table 7). This form was followed by those in the form of stingers, very dense in the fruit and with a length up to $10 \mathrm{~mm}(18 \%)$ and the spines erect with acute apex and rounded at its base with a length up to $2 \mathrm{~mm}(17 \%)$. The form of spines could be linked to specific genetic structures, so complementary research on this subject should be initiated. 
Table 7. Forms of spines of the exocarp that predominate in the in situ soursop germplasm from southern of Manabí, Ecuador.

\begin{tabular}{|l|l|l|}
\hline \multicolumn{2}{|c|}{$\begin{array}{l}\text { Form of spines } \\
\text { of the exocarp }\end{array}$} & \multicolumn{1}{c|}{ Description } \\
\hline Erect spines with acute apex and rounded at its base, with a height up \\
to $2 \mathrm{~mm}$.
\end{tabular}

In general, there are few studies about the characteristics of the exocarp spines and the soursop fruit forms that provide precise details and definitions about them (Moreira et al., 2016). Spines are simply called "spine" and the fruits in most cases it is attributed a cordiform, oval and conical aspect (Benavides, 1997, Miranda et al., 2000, Pinto et al., 2005).

\section{Conclusion}

Based on the results found in the wild soursop population in Manabí, it is possible to conclude the existence of high variability, especially in comparison with other similar studies conducted in other regions of the world.

In this study it was possible to observe high values of variation coefficients, ranges, explanation of the variability in the principal components analysis, as well as the diverse phenotypic expression of qualitative characteristics in leaves and fruits, which until now have not been reported so widely by others studies.

The existence of attributes of the plant and the different organs that make it up, especially the number and shapes of the fruit, shapes and dimensions of the leaf, among others, undoubtedly represent some elements of great value to be used in the genetic improvement of this species. 


\section{References}

Benavides, G. A. (1997). Caracterización numérica del germoplasma de guanábana (Annona muricata L.) muestreado in situ en el Pacífico y norte de Nicaragua. Nicaragua: Universidad Nacional Agraria-Programa de Recursos Fitogenéticos Nicaragüenses.

Bioversity International y CHERLA. (2008). Descriptores para chirimoyo (Annona cherimola Mill). Bioversity International, Roma, Italia: Proyecto CHERLA, Málaga, España, 51 pp.

Castañeda, S. L. (2014). Evaluación morfológica y molecular de accesiones de anonáceas (Anón, chirimoya y atemoya) en condiciones in situ de las regiones andinas y Caribe colombiano. Agrarias. Tesis de Investigación presentada como requisito parcial para optar al título de Magíster en Ciencias Agrarias, Área de Genética y Fitomejoramiento. Universidad Nacional de Colombia, Facultad de Ciencias., $147 \mathrm{pp}$.

Constance, N., Brisibe, E.A., Nkachukwu, P. y Aniedi, E. (2015). Molecular and morphological marker reveal exploitable diversity in soursop (Annona muricata L.). Industrial Biotechnology Congress Biotechnology. Biomater 5 (2): 41.

Di Rienzo, J. A., Casanoves, F., Balzarini, M. G., González, L., Tablada, M. y Robledo. C. W. (2016). InfoStat versión 2016. Grupo Infostat, FCA, Universidad Nacional de Córdoba, Argentina., URL http:// www.infostat.com.ar.

Franco, T. L., e Hidalgo, R. (Eds.). (2003). Análisis estadístico de datos de caracterización morfológica de recursos fitogenéticos. Boletín Técnico n. ${ }^{\circ}$ 8. Cali, Colombia. Instituto Internacional de Recursos Fitogenéticos (IPGRI), 89.

Hernández, V. A. (2013). Caracterización morfológica de recursos fitogenéticos. Revista Biociencias, 2 (3): 113-118.

INAMHI (Instituto Nacional de Metereología y Hidrología). 2014. Anuario Meteorológico n.51, 149 pp. Jameel, M.; Mohan, S. y Johnson, D. (Eds.). (2015). Advances in Plant Breeding Strategies". In Breeding, Biotechnology and Molecular Tools. Vol. 1. USA: Springers International Publishing, 656 pp.

Jemimah, O., Obaineh, M. y Muhammad, A. 2016. Comparative Phytochemistry and Antioxidant Activities of Water and Ethanol Extract of Annona muricata Linn Leaf, Seed and Fruit. Advances in Biological Research. 10 (4): 230-235.

Love, K., y Paull, R. (2011). Soursop. College of Tropical Agriculture and Human Resources, University of Hawai at Manoa. UH-CTAHR. F-N-22, 6 pp.

Meza, N., y Bautista, D. (1999). Estimación del área foliar en plantas jovenes de níspero (Manilkara achras (Miller) Fosgber) sometidas a dos ambientes de luz. Bioagro, 11 (1): 24-28.

Miranda, D., Arce, C., Gómez, L., Vasto, D., Arboney, J. y Bravo, A. (2000). Conozcamos el cultivo de Guanábana. Cartilla divulgativa. CORPOICA Regional 6. Caracterización de cultivares de guanábana (Annona muricata L.). Guanábana MIC., 252 pp.

Moreira R. y Héctor E. (2014). Estado actual y perspectivas de desarrollo de la guanábana (Annona muricata L.) como cultivo comercial en el sur de Manabí, Ecuador". Alternativas. 15 (2), 36-42.

Moreira M. R., Héctor A. E, Uguña. R. F., Franco F. F. y Rodríguez A. D. (2016). Variabilidad físico-química de frutos de guanábana (Annona muricata L.) de una población in situ del sur de Manabí, Ecuador. Agrotecnia de Cuba, 40 (1): 34-46

Pro Ecuador. "Boletín Mensual de Comercio Exterior-Ministerio de Comercio Exterior. Dirección de Inteligencia Comercial e Inversiones". 2014. Disponible en: http://www.proecuador.gob.ec/wp-content/uploads/2014 /04/BOLETIN-MARZO-ABRIL-INAL.pdf. (Consultado: 20 de junio de 2016).

Suratman, A. P., y Mulyani, S. (2015). Assement of genetic diversity among soursop (Annona muricata) populations from Java, Indonesia using RAPD markers. Biodiversitas, 16 (2): 247-253.

Padmini, S. M., Pushpakumara, D. y Samarasekera, R. 2013. Morphological characterization of Soursop (Annona muricata L.) Germplasm in Sri Lanka. Tropical Agriculture Research, 24 (4): 362-374. 
Pinto, A. C., Cordeiro, M., Andrade, M., Ferreira, F., Filgueira, H., Alves, R. \& Kimpara, D., 2005. Annona species. International Centre for Underutilized Crop. University of Southampton. S017 IBJ. UK. 268 pp.

Zorofchian, S., Fadaeinasab, M., Nikzad, S., Mohan, G., Mohd, H. \& Abdul, Y.H. 2015. "Annona muricata (Annonaceae): A Review of Its Traditional Uses, Isolated Acetogenins and Biological Activities". Int. J. Mol. Sci., 16:15625-15658. doi: 10.3390/ijms160715625. 